\title{
Electrophoretic study on intraspecific variations and interspecific relationships of marine catfishes (Siluriformes, Ariidae) of Cananéia (São Paulo, Brazil). 2. Isozymes of skeletic muscle.
}

\author{
Hana SUZUKI \& PHAN Van Ngan
}

Instituto Oceanográfico da Universidade de São Paulo

(Caixa Postal 9075, 01051, São Paulo, SP)

- Abstract: Ten enzymatic systems of skeletic muscle of four species of marine catfishes were analysed by polyacrylamide flat gel electrophoresis. Out of 17 loci examined, six were polymorphic. The heterozygosities varied from 0.0018 to 0.0755 , the proportions of polymorphic loci, from 0.0588 to 0.2353 and the genetic identities I of Nei, from 0.242 to 0.822 . The degree of genetic identity among the species is illustrated by UPGMA dendrograms.

Descriptors: Electrophoresis, Muscles, Isoenzymes, Biopolymorphism, Interspecific relationships, Ariidae, Cananéia: SP.

Descitores: Eletroforese, Músculo, Isoenzimas, Biopolimorfismo, Relaçōes interespecíficas, Ariidae, Cananéia: SP.

\section{Introduction}

In our earlier paper (Suzuki \& Phan, 1990), general proteins of eye-lens and skeletic muscle were electrophoretically analysed in order to investigate intraspecific variations and interspecific relationships of six species of marine catfish from Cananéia (São Paulo, Brazil). In this paper ten enzymatic systems of skeletic muscle of four species, Netuma barba, Genidens genidens, Sciadeichthys luniscutis and Cathorops spixii, were analysed and isozyme polymorphisms and interspecific relationships were investigated.

The development of zone electrophoresis (Smithies, 1955) coupled with histochemical staining techniques (Hunter \& Markert, 1957) contributed enormously to the knowledge of isozymes, defined as multiple forms of enzymes possessing the same activity and arising from genetic control of primary protein structure (Markert \& Moller, 1959). Isozymic investigations have been considered very useful and suitable for studies on genetic divergence at different levels of the evolutionary differentiation, including phylogenetic systematics (Selander \& Johnson, 1973; Avise, 1974; Ayala, 1975; Avise \& Smith, 1977).

$\overline{\text { Contr. } n^{\circ} 715}$ do Inst. oceanogr. da Usp.

\section{Material and methods}

The catfishes were collected between February 1981 and August 1985. Procedures of sampling of skeletic muscle and preparation of extracts were described in the previous paper (Suzuki \& Phan, 1990). Ten enzymes were investigated (abbreviation and Enzyme Commission number are in parentheses): lactate dehydrogenase (LDH; 1.1.1.27), malate dehydrogenase (MDH; 1.1.1.37), malic enzyme (ME; 1.1.1.40), isocitrate dehydrogenase (IDH; 1.1.1.42), aldehyde oxidase (AO; 1.2.3.1), tetrazolium oxidase (TO; 1.15.1.1.), aspartate amino-transferase (AAT; 2.6.1.1.), esterases (Est; 3.1.1.1.), alcaline phosphatase (APH; 3.1.3.1) and acid phosphatase (ACPH; 3.1.3.2).

Two vertical polyacrylamide slab gel electrophoresis systems were selected after a number of tests in order to find out the methods yielding the best resolution for each isozyme:

System 1: one layer gel of concentration 10\% (Akroyd, 1968); gel buffer Tris-citrate pH 7.0 (Shaw \& Prasad, 1970); electrode buffer Tris-glycine pH 8.9 (Tris $0.0165 \mathrm{M}$ and glycine $0.1279 \mathrm{M}$, adjusted to $\mathrm{pH} 8.9$ with $1 \mathrm{~N} \mathrm{NaOH}$ ). This system was used for MDH and ACPH.

System 2: two layer gel electrophoresis described by Phan et al. (1985). This system was used for LDH, ME, IDH, AO, AAT, Est and APH. 
The electrophoresis was carried out at $5^{\circ} \mathrm{C}$ and with an inox box containing grinded ice in front of the gel to further minimize the heat generated by the electrophoretic system.

Attempts to visualise isozymes of $\mathrm{ME}, \mathrm{IDH}, \mathrm{APH}$ and $\mathrm{ACPH}$ of liver and heart samples with the system 2 of buffers failed to give good resolution.

The amount of extract, electrophoretic system, time of electrophoretic run, staining procedure and staining buffer for each enzyme are summarized in Table 1. The bands attributed to TO were the clear bands obtained against a bluish background on gels stained for any of the oxidoreductases and exposed to ligth. The gels were photographed, kept in $7 \%$ acetic acid in $5 \%$ glycerol overnigth and then dried with a heat vacuum dryer.

Nomenclature of loci and electromorphs followed the system of Allendorf \& Utter (1979). A locus was considered polymorphic when the most common electromorph had a frequency of less than 0.99. Data from all individuals of each species were used to calculate electromorph frequencies at all loci. Chi-square goodness-of-fit analysis was used to test the samples for Hardy-Weinberg equilibrium. The Yates' correction (Dixon \& Massey, 1969) for small samples was not applied because of its effect of increasing the type II error in genetic models (Fairbain \& Roff, 1980). In each of the four species, N. barba, G. genidens, S. luniscutis and C. spixii, genetic variation was estimated by the proportion of polymorphic loci $(\mathrm{P})$ and the mean observed $(\mathrm{Ho})$ and expected $(\mathrm{He})$ heterozygosities over all loci studied (Nei, 1978). Deviations from Hardy-Weinberg expectations were measured by the heterozygote deficiency, Hd (Selander, 1970) where $\mathrm{Hd}=(\mathrm{Ho}-\mathrm{He}) / \mathrm{He}$. The coefficient of genetic distance D of Nei (1972) and its standard error (Nei , 1971), the coefficient of genetic distance of Rogers (1972) and of Thorpe (1979) as well as coefficient of genetic identity I of Nei (1972) were determined for each pair of these species. From the matrix of coefficient I, UPGMA dendrograms (Sneath \& Sokal, 1973) were constructed to represent the degree of genetic identity among the species.

\section{Results}

The electromorph frequencies of 17 presumptive gene loci detected from ten enzymatic systems and their standard errors, and the number of individulas of each species used for the analyses are presented in Table 2.

Out of the 17 loci, 6 (MDH-2, ME, IDH-1, IDH-3, TO and Est) were polymorphic. Deviations of the observed heterozygosities from the Hardy-Weinberg expectations at these polymorphic loci are shown in Table 3. Significant $(\mathrm{P}<0,05)$ heterozygote deficiencies were found for $\mathrm{ME}$ of $C$. spixii and for TO of G. genidens. Table 4 summarizes the electrophoretically detectable genetic variation in the four species of marine catfish. The lowest level of genetic variability was found in $N$. barba with $\mathrm{Ho}=0.0018$ and $\mathrm{P}$ $=0.0588$ and the highest level of genetic variability, in $C$. spixii with $\mathrm{Ho}=0.0755$ and $\mathrm{P}=0.2353$.
In order to investigate if the isozyme variability was related to the enzyme function, the observed heterozygosities were classified into enzyme functional classes. Three classifications were considered: (1) glucose-metabolizing (Group G) and nonspecific (Group NG) enzymes (Gillespie \& Kojima, 1968); (2) single substrate (Group I) and variable substrate (Group II) enzymes (Gillespie \& Langley, 1974); (3) regulatory (R), non- regulatory (NR) and variable substrate (V) enzymes (Johnson, 1974). Significant differences were not found in the heterozygosities of enzymes of different classes of any classification (Tab. 5).

Relationships between the isozyme variability (Ho) and ecological and biological characteristics of the catfishes were analysed by Spearman's rank correlation (Siegel, 1981). The following variables used were: maximum length of the species (our observation), abundance in the Cananéia region (Mishima \& Tanji, 1981), trophic level (Mishima \& Tanji, 1982) and observed heterozygosity (present paper). The analysis (Tab. 6) indicated a significant correlation between trophic level and maximum length and between heterozygosity of group I enzymes and total heterozygosity.

The Nei's coefficients, the genetic identity I and the genetic distance $\mathrm{D}$ and their standard errors, are given in Table 7. The genetic distance of Rogers (1972) and of Thorpe (1979) are given in Table 8. The UPGMA dendrogram constructed from the matrix of coefficient I is shown in Figure 1. This dendrogram was congruent with that constructed from composite coefficients of similarity obtained by band-counting method from data of eye-lens electropherograms combined with those of skeletic muscle electropherograms (Suzuki \& Phan, 1990). In both dendrograms, $N$. barba and $G$. genidens appeared to be the most closely related and $S$. luniscutis to be the most divergent among the four species.

\section{Discussion}

The level of genetic variability in four species of marine catfish, $N$. barba, G. genidens, S. luniscutis and $C$. spixii, was estimated by the observed heterozygosity (Ho) and the proportion of polymorphic loci $(\mathrm{P})$. The values found were within the limits of variation for marine fishes (Fujio \& Kato, 1979; Gyllensten, 1985; Johnson et al., 1973; Shaklee et al., 1982; Smith \& Fujio, 1982; Somero \& Soulé, 1974) although a little lower than the average value of Ho $=0.10$ presented in the review of Ferguson (1980) dealing with various organisms. Nevo (1978) compared genetic variabilities of vertebrates, invertebrates and plants and found that the lowest values occur in vertebrates and the highest in invertebrates.

No significant correlation between the heterozygosity and other variables such as maximum length of the species, abundance. in the sampling region and trophic level, was found. The heterozygosity of marine teleosts, as opposed to that of other vertebrates and of invertebrates, is little influenced by the animal size but is positively related with its geographic distribution extent (Smith \& Fujio, 1982). 
Table 1. Summary of electrophopresis and staining of enzymes of skeletic muscle

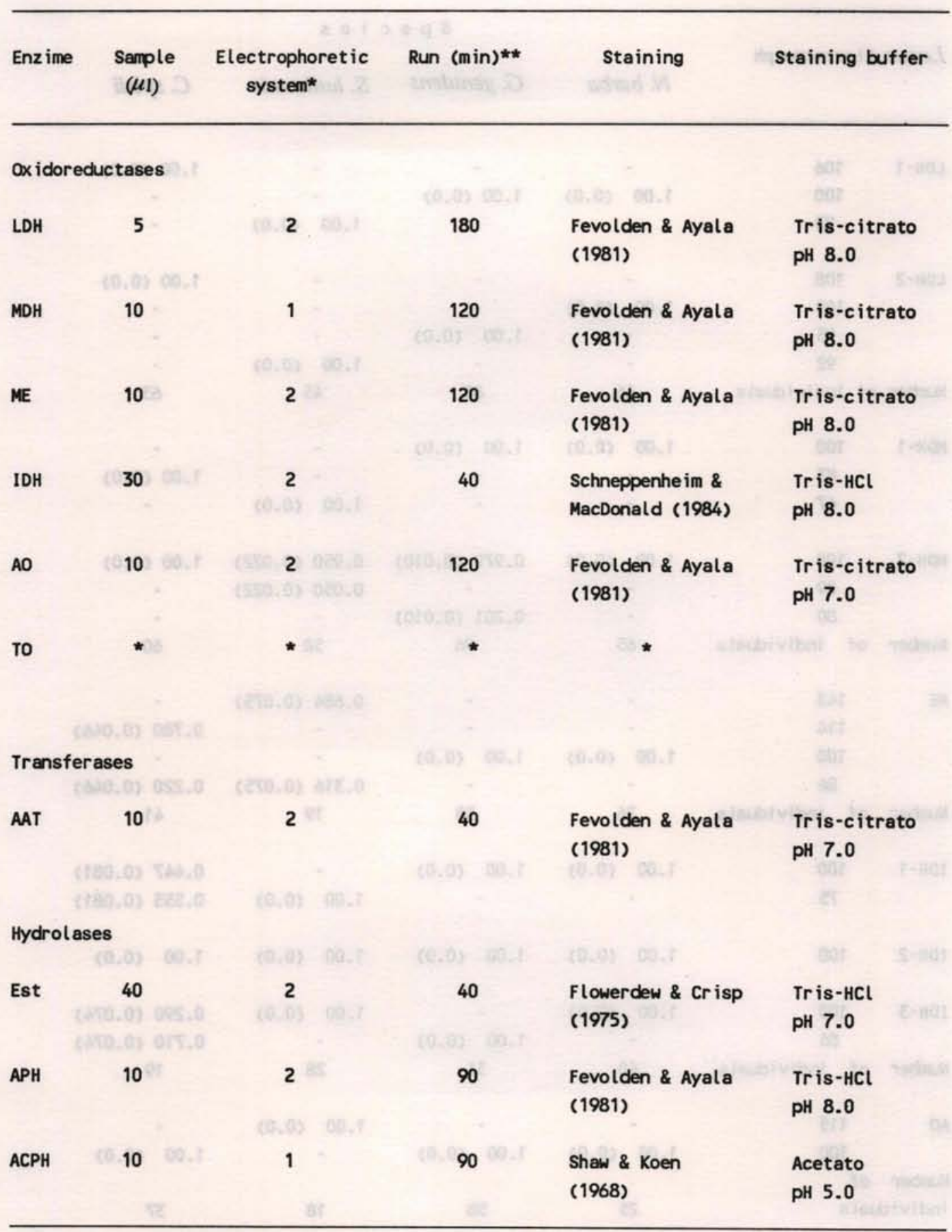

* = See details on page 43

** = Run time in the lower gel 
Table 2. Frequencies and standard errors (between parenthesis) of electromorphs of 17 enzymatic loci in the four species of marine catfish and the number of individuals used for the analyses

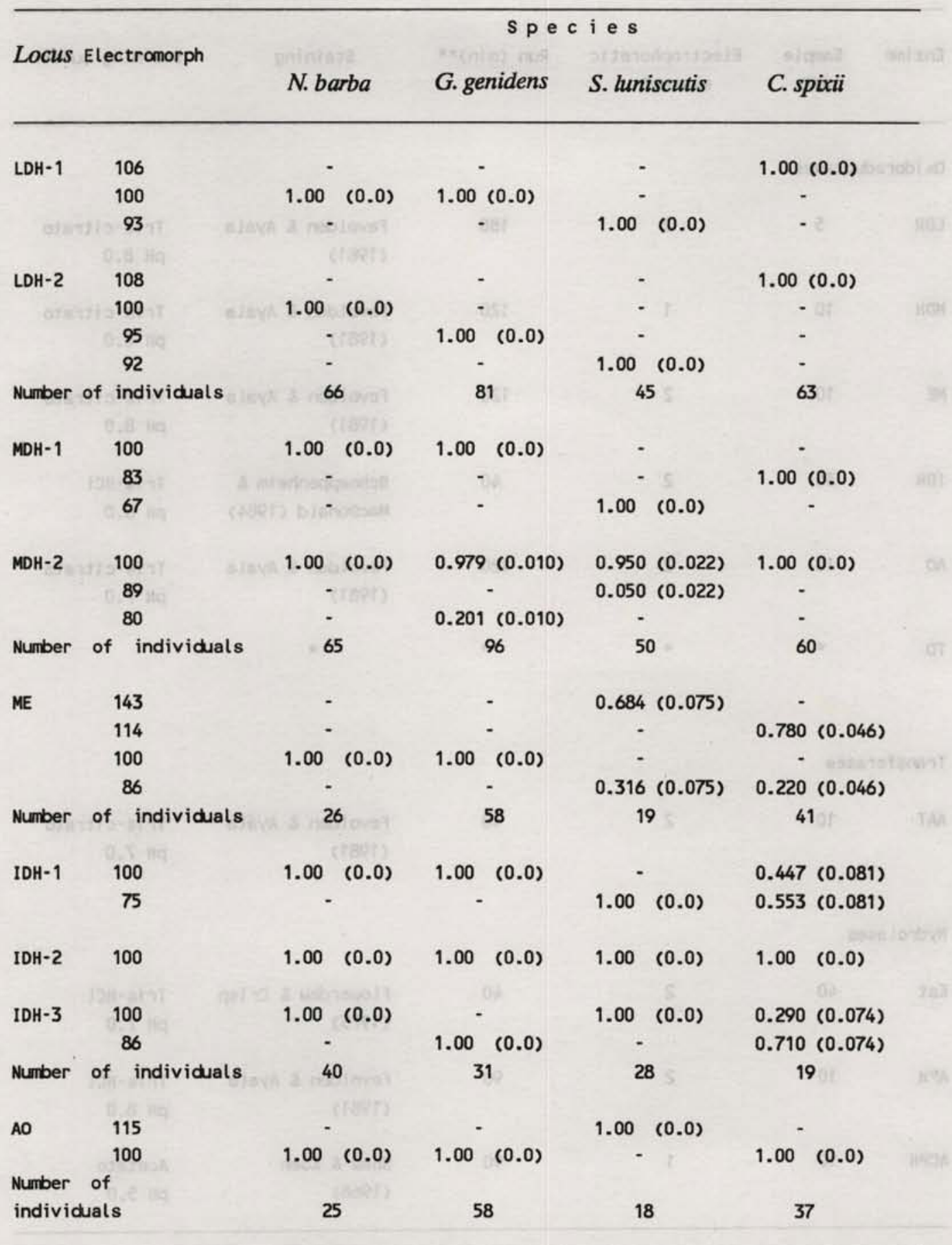


Table 2. Cont.

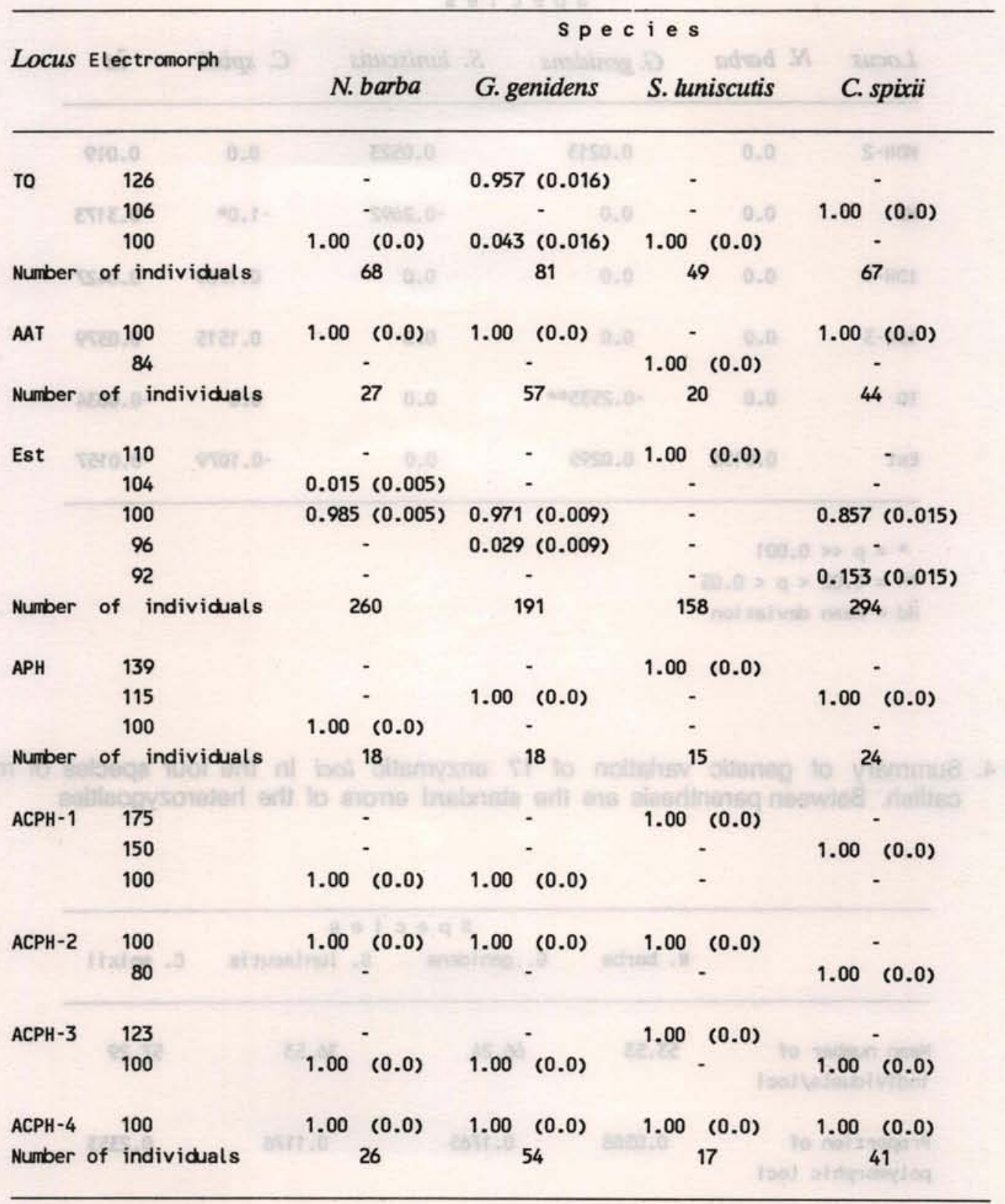


Table 3. Deviations $(\mathrm{Hd}=(\mathrm{Ho}-\mathrm{He}) / \mathrm{He})$ in relation to the Hardy-Weinberg expectations for each polymorphic locus, in the four species of marine catfish

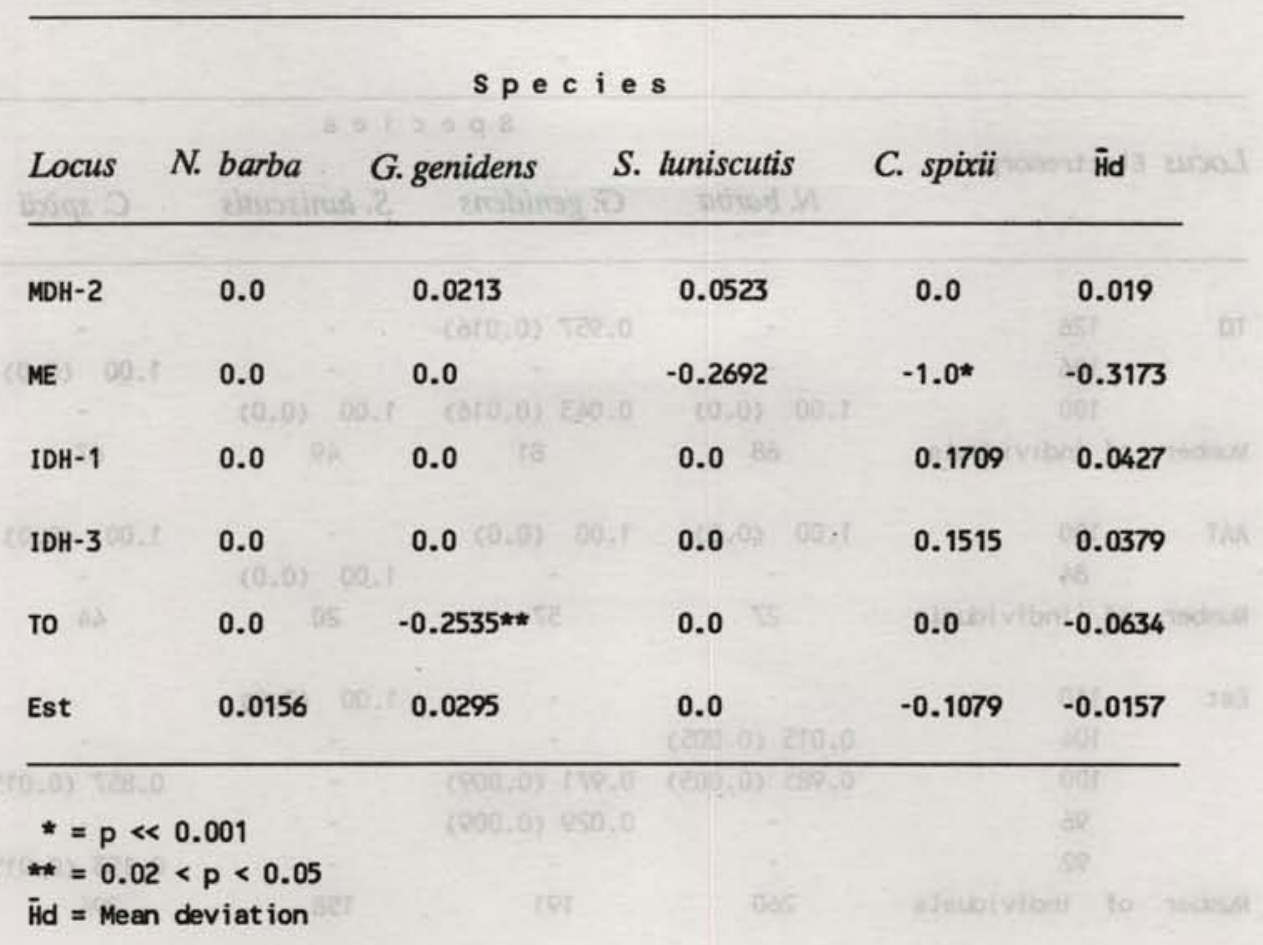

Table 4. Summary of genetic variation of 17 enzymatic loci in the four species of marine catfish. Between parenthesis are the standard errors of the heterozygosities

\begin{tabular}{|c|c|c|c|c|c|}
\hline \multirow[b]{2}{*}{$(6,8) \quad(80.1)$} & \multicolumn{5}{|c|}{ species } \\
\hline & N. barba & G. genidens & s. & luniscut is & c. spixii \\
\hline $\begin{array}{l}\text { Mean number of } \\
\text { individuals/loci }\end{array}$ & 53.53 & 66.24 & (25:64) & 36.53 & 57.29 \\
\hline $\begin{array}{l}\text { Proportion of } \\
\text { polymorphic loci }\end{array}$ & 0.0588 & 0.1765 & $(120)$ & 0.1176 & 0.2353 \\
\hline $\begin{array}{l}\text { Mean observed } \\
\text { heterozygosity }\end{array}$ & $\begin{array}{c}0.0018 \\
(0.0018)\end{array}$ & $\begin{array}{c}0.0095 \\
(0.0052)\end{array}$ & & $\begin{array}{l}0.0245 \\
(0.0191)\end{array}$ & $\begin{array}{c}0.0755 \\
(0.0436)\end{array}$ \\
\hline $\begin{array}{l}\text { Mean expected } \\
\text { heterozygosity }\end{array}$ & $\begin{array}{c}0.0018 \\
(0.0018)\end{array}$ & $\begin{array}{c}0.0106 \\
(0.0061)\end{array}$ & & $\begin{array}{c}0.0310 \\
(0.0257)\end{array}$ & $\begin{array}{l}0.0887 \\
(0.0413)\end{array}$ \\
\hline $\begin{array}{l}\text { Meen deficiency } \\
\text { of heterozygotes }\end{array}$ & 0.0009 & -0.0119 & & -0.0127 & -0.0462 \\
\hline
\end{tabular}


Table 5. Observed heterozygosity $(\mathrm{Ho})$ of enzymes of different functional classes

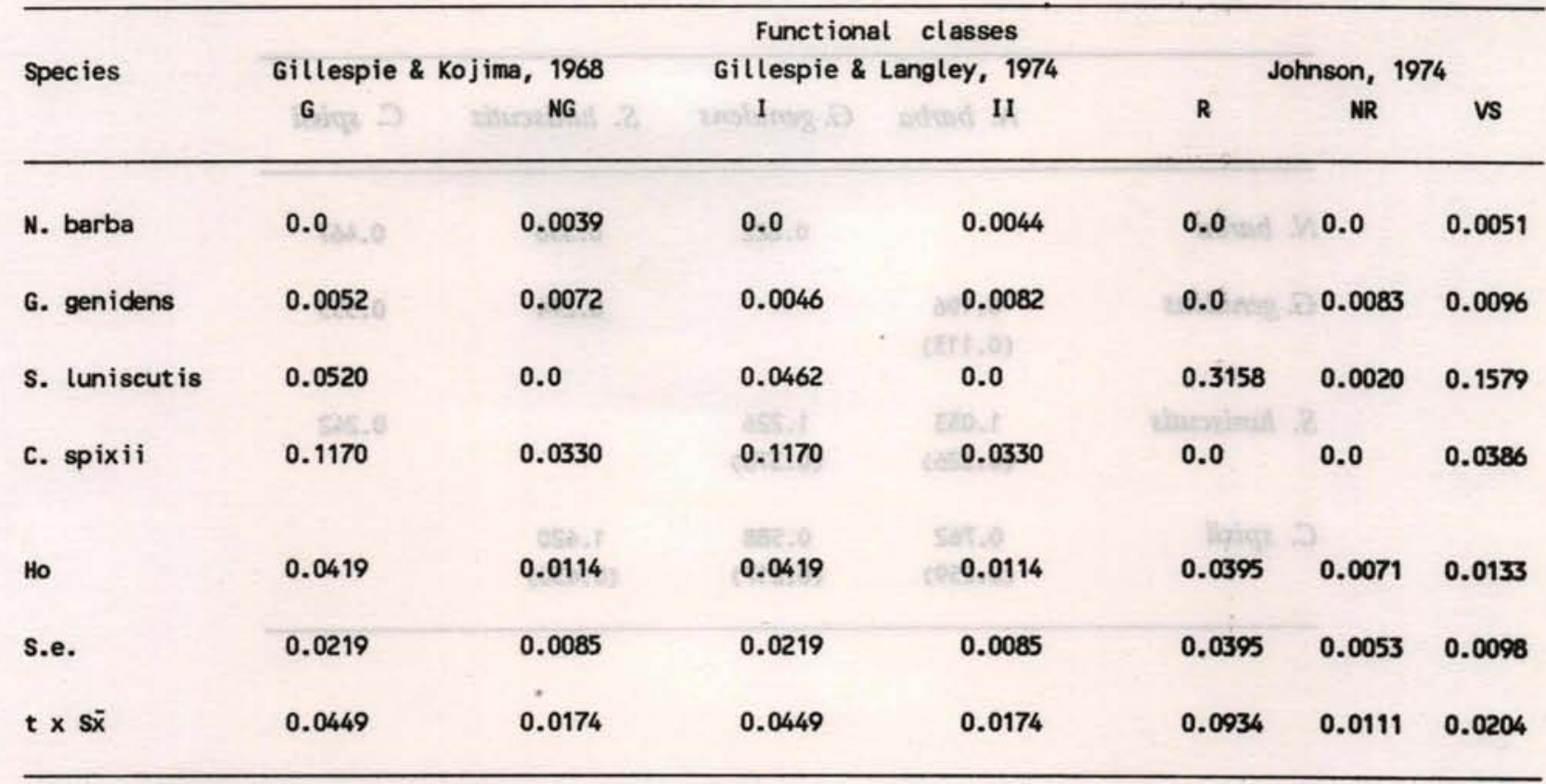

s.e. = standard error

$t \times S \bar{x}=$ Conf idence interval (level of, $5 \%$ )

Table 6. Spearman rank correlation coefficients between the observed heterozygosity and biological and ecological characteristics

\begin{tabular}{|c|c|c|c|c|c|}
\hline weth in & Abundance & $\begin{array}{c}\text { Trophic } \\
\text { level }\end{array}$ & $\begin{array}{l}\text { Ho of } \\
\text { group I }\end{array}$ & $\begin{array}{l}\text { Ho of } \\
\text { group II }\end{array}$ & Ho \\
\hline Length & -0.40 & $1.0^{*}$ & -0.80 & -0.80 & -0.80 \\
\hline Abundance & & -0.40 & -0.07 & 0.80 & -0.07 \\
\hline Trophic level & & & -0.80 & -0.80 & -0.80 \\
\hline Ho of group I & & - & & 0.40 & $1.0^{*}$ \\
\hline Ho of group II & & & & & 0.40 \\
\hline
\end{tabular}

* = significant at level of $5 \%$ 
Table 7. Coefficients of genetic identity I (above diagonal) and genetic distance $D$ (below diagonal) between species of marine catfish, based on 17 enzymatic loci. Between parenthesis are the standard erros of genetic distances D

\begin{tabular}{lcccc}
\hline & $N$ barba & G. genidens & S. huniscutis & C. spixii \\
\hline N. barba & & 0.822 & 0.356 & 0.467 \\
G. genidens & 0.196 & & 0.294 & 0.555 \\
& $(0.113)$ & & & \\
S. luniscutis & 1.033 & 1.226 & & 0.242 \\
& $(0.326)$ & $(0.376)$ & & \\
C. spixii & 0.762 & 0.588 & 1.420 & \\
& $(0.259)$ & $(0.217)$ & $(0.430)$ & \\
\hline
\end{tabular}

GENETIC IDENTITY
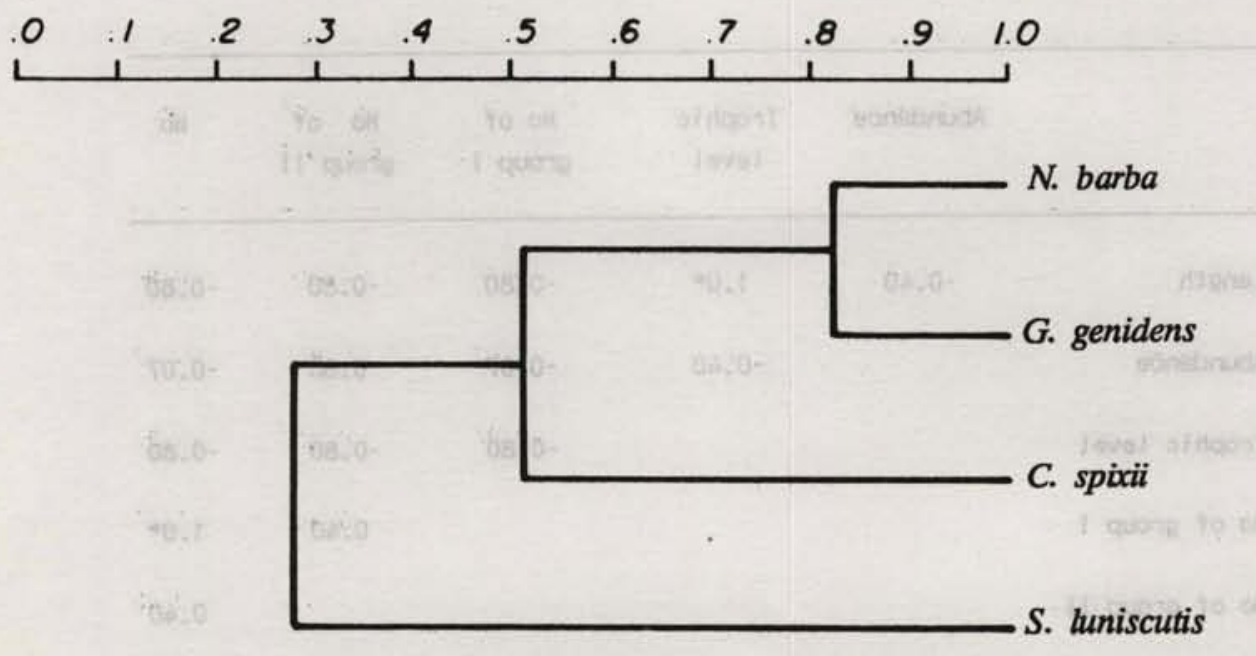

Fig. 1. UPGMA dendrograms showing the relationships among the four marine catfish, based on coefficients of genetic identity I (Nei, 1972) obtained from 17 enzymatic loci data. 
Table 8. Genetic distance of Rogers (1972) (above diagonal) and of Thorpe (1979) (below diagonal) between pairs of species of marine catfish, base on 17 enzymatic loci

$\begin{array}{llll}\text { N. barba } & \text { G.genidens } & \text { S. luniscutis } & \text { C. spixii }\end{array}$

$\begin{array}{lllll}\text { N. barba } & & 0.182 & 0.643 & 0.548 \\ \text { G. genidens } & 0.182 & & 0.703 & 0.463 \\ \text { S. } \text { luniscutis } & 0.650 & 0.711 & & 0.758 \\ \text { C. } \text { spixii } & 0.554 & 0.470 & 0.764 & \end{array}$

It is suggested that the genetic variability might be related with the physiological function of the enzyme and theory of higher variability for enzymes of variable and nonspecific substrate has been presented (Gillespie \& Kojima, 1968; Gillespie \& Langley, 1974; Johnson, 1974). On the other hand, as opposed to this theory, Anderson (1982) argued that the enzymes of variable substrate might need a primary structure highly conservative in order to maintain the functional flexibility. Results of some investigations agree with the Anderson's argument (Frydenberg \& Simonsen, 1973; Smith \& Jamieson, 1980). Influence of the enzymatic function on the level of genetic variability of the marine catfishes was not found since enzymes of different functional classes did not show significant differences in heterozygosities. Similar results were also reported for marine teleosts (Smith \& Fujio, 1982) and marine molluscs (Fujio et. al., 1983).

Regarding deficiency of heterozygotes, relatively few examples are known for marine teleosts (Fujio et al., 1983; Richardson, 1982; Smith, 1979; Smith et al., 1981; Smith \& Francis, 1984). The mechanisms inducing the deficiencies observed in marine catfishes are not known. Some hypothesis, such as mis-scoring of gel phenotypes, inbreeding, selection against heterozygotes, Wahlund effect and sampling error, might have contributed to these results and they must not be mutually exclusive.

Regarding interspecific relationships among $N$. barba, G. genidens, $S$. luniscutis and $C$. spixii, the dendrogram constructed from the isozyme data showed the same topology as the dendrograms constructed from eye-lens data combined with skeletic muscle data (Suzuki \& Phan, 1990). Both dendrograms showed that N. barba and G. genidens are very similar and more closely related to $C$. spixii than to $S$. luniscutis. These biochemical results agree with osteological study of Higuchi (1982) concerning the similarity between $N$. barba and $G$. genidens but the distinction of S. luniscutis was not apparent in the osteological features.

There is much controversy about the evolutionary concordance between biochemical and morphological characters. Lewontin (1984) demonstrated how different are the powers of statistical tests for the two kinds of characters and pointed out the lack of information on how many loci are involved in the morphological characters. The lack of congruence between these two data sets might result from a non-satisfactory sampling of the genome of the organisms. As the majority of the biochemical studies can examine only about $0.1 \%$ of the structural genes, the genes responsible for the morphological differentiation might be among the structural genes which are not amenable to electrophoretic techniques or might be related to regulatory genes systems (Avise \& Ayala, 1976; King \& Wilson, 1975). Another reasonable explanation for the discordance between biochemical and morphological data sets is the mosaic evolution which can be caused by plesiomorphy of one set while the other is evolving (Mickevich \& Johnson, 1976). In fish, examples of morphological characters more diversified than the biochemical ones (Sage \& Selander, 1975; Turner \& Grosse, 1980; Yoshiyama \& Sassaman, 1983) and vice-versa (Saunders \& McKenzie, 1971) are known.

Arguments concerning which data set, biochemical or morphological, yields the most realistic classification and relationship between the species, could continue endlessly. According to Ferguson (1980) there are not $a$ priori reasons to suggest which classification is the most valuable and it must be considered that no single 
classification could encompass the diverse sets of informations. Electrophoretic methods cannot be used as a substitute for morphological analysis but as a complement to it (Avise, 1974; Bruce \& Ayala, 1979) because they frequently reveal relationhsips that are not readily discernible morphologically (Tsuyuki $e t$ al., 1965).

The coefficients of genetic identity I (Nei, 1972) between pairs of species of arïd catfishes varied from 0.242 (between $S$. luniscutis and $C$. spixii) to 0.822 (between $N$. barba and $G$. genidens). The average obtained was 0.456 with standard deviation 0.213 , value comparable to the intergeneric I $(0.40)$ calculated by Shaklee et al. (1982) based on various groups of fish. However, the I between $N$. barba and $G$. genidens $(0.822)$ was relatively high for non-congeneric species and might suggest a very close relationship and probably a recent divergence between these species.

Comparisons of coefficients I and D of different groups of organisms must be made cautiously since it is known that the evolutionary rate is distinct for each group of organisms and the degree of divergence in structural genes is not equivalent in the different classes of vertebrates (Avise \& Aquadro, 1982). Nevertheless, Shaklee et al. (1982) argued that estimations of genetic coefficients can be useful as a reference for interpretations of the results related to the taxonomic status of organisms under investigation.

Consulting the curves of probability against coefficient I for different levels of evolutionary divergence (conspecific populations, congeneric species and confamilial genera) (Thorpe, 1982), the I between $N$. barb $a$ and $G$. genidens $(0.822)$ is threefold the average I for confamilial genera (0.273), 1.5 times the average I for congeneric species $(0.54)$ and is found near the upper limit (approximately 0.85 ) of the probability of $I$ for this level of evolutionary divergence.

In view of the fact that intergeneric I between $N$. barba and $G$. genidens is higher than those found between genera of other organisms, some hypothesis can be put forward. There might be a very close relationship and a recent divergence between these species. Occurrence of homoplasy, different evolutionary rate for each species and a non-representative sampling of genome of these organisms (Avise \& Ayala, 1976) must also be considered. Furthermore, electrophoresis provides direct evidence of the differences between electrophoretic bands which present distinct mobilities under certain run conditions, but bands of same position do not necessarily mean that they are structurally identical (Johnson, 1977).

It is not our intention to interpret the genetic coefficients quantitatively in order to establish the taxonomic status of catfishes under investigation. However, the coefficients estimated and the interspecific relationships illustrated in the dendrograms of this and the previous paper (Suzuki \& Phan, 1990) confirm the need of a revision in the supraspecific levels of the family Ariidae as pointed out by Higuchi (1982) and Higuchi et al. (1982). For the systematic revision of the family Ariidae, further biochemical studies dealing with more characters in order to minimize the convergence effects (Sneath \& Sokal, 1973), more species of Ariidae and other families of the Order Siluriformes, greater distribution area for each species and phylogenetic relationships, would be of great value.

\section{Resumo}

Dez sistemas enzimáticos do músculo esquelético de quatro espécies de bagres marinhos foram analisados eletroforeticamente em géis de poliacrilamida. As heterozigosidades observadas variaram entre $0,0018 \mathrm{e}$ 0,0755 , as proporçōes de loci polimórficos, entre 0,0588 e 0,2353, e as identidades genéticas I de Nei, entre 0,242 e 0,822 . O grau de identidade genética entre as espécies foi ilustrado através de dendrogramas UPGMA.

\section{Acknowledgements}

We are grateful to Dr. Vicente Gomes and Mrs. Maria José A. C. R. Passos for their aid in sampling and laboratory analyses. This work was supported by grants from FAPESP (80/1694-0) and CNPq (10.1739/82 and 40.0528/82).

\section{References}

AKROYD, P. 1968. Vertical flat-bed electrophoresis. In: Smith, I. ed. Chromatographic and electrophoresis techniques. William Heinemann, Medical Books. p.458-474.

ALLENDORF, F. W. \& UTTER, F. M. 1979. Population genetics. In: Hoar, W. S.; Randall, D. J. \& Brett,J. R. eds., Fish Physiology. Bioenergetics and growth. New York, Academic Press. v.8, p.407-454.

ANDERSON, R. C. 1982. Isozyme variation in euphausiids. Ph.D. Thesis. University of East Anglia.

AVISE, J. C. 1974. Systematic value of electrophoretic data. Syst. Zool, 23:465-481.

\& AQUADRO, C. F. 1982. A comparative summary of genetic distances in the vertebrates. Evol. Biol., 15:151-185.

\& AYALA, F. J. 1976. Genetic differentiation in speciose versus depauparate phylads: evidence from the California minnows. Evolution, 30:46-58.

\& SMITH, M. H. 1977. Gene frequency comparisons between sunfish (Centrarchidae) populations at various stages of evolutionary divergence. Syst. Zool, 26:319-335.

AYALA, F. J. 1975. Genetic differentiation during the speciation process. Evol. Biol., 8:1-78. 
BRUCE, E. J. \& AYALA, F. J. 1979. Phylogenetic relationships between man and the apes: electrophoretic evidence. Evolution, 33:1040-1056.

DIXON, W. J. \& MASSEY Jr, F. J. 1969. Introduction to statistical analysis. 3rd ed. New York, McGraw-Hill.

FAIRBAIN, D. J. \& ROFF, D. A. 1980. Testing genetic models of isozyme variability without breeding data: can we depend on the $\mathrm{X}^{2}$ ? Can. J. Fish. aquat. Sci., 37:1149-1159.

FERGUSON, A. 1980. Biochemical systematics and evolution. Glasgow, Blackie. 194p.

FEVOLDEN, S. E. \& AYALA, F. J. 1981. Enzyme polymorphism in Antarctic krill (Euphausiacea): genetic variation between populations and species. Sarsia, 64:167-181.

FLOWERDEW, M. W. \& CRISP, D. J. 1975. Esterase heterogeneity and an investigation into racial differences in the cirripede Balanus balanoides using acrylamide gel electrophoresis. Mar. Biol., 33:33-39.

FRYDENBERG, O. \& SIMONSEN, V. 1973. Genetics of Zoarces populations. V. Amount of protein polymorphism and degree of genic heterozygosity. Hereditas, 75:221-232.

FUJIO, Y. \& KATO, Y. 1979. Genetic variation on fish populations. Bull. japan. Soc. scient. Fish., 45:1169-1178.

; YAMANAKA, R. \& SMITH, P. J. 1983. Genetic variation in marine molluscs. Bull. japan. Soc. scient. Fish., 49:1809-1817.

GILLESPIE, J. H. \& KOJIMA, K. 1968. The degree of polymorphisms in enzymes involved in energy production compared to that in non-specific enzymes in two Drosophila anassae populations. Proc. natn. Acad. Sci. U.S.A., 61:582-585.

\& LANGLEY, C. H. 1974. A general model to account for enzyme variation in natural populations. Genetics, 76:837-848.

GYLLENSTEN, U. 1985. The genetic structure of fish: differences in the intraspecific distribution of biochemical genetic variation between marine, anadromous, and freshwater species. J. Fish Biol., 26:691-699.

HIGUCHI, H. 1982. Estudo osteológico de bagres marinhos do litoral sul do Brasil (Osteichthyes; Siluroidei, Ariidae). Dissertação de mestrado. Universidade de São Paulo, Instituto de Biociências. $135 \mathrm{p}$.
HIGUCHI, H.; REIS, E. G. \& ARAÚJO, F. G. 1982. Uma nova espécie de bagre marinho do litoral do Rio Grande do Sul e consideraçōes sobre o gênero nominal Netuma Bleeker, 1858 no Atlântico Sul Ocidental (Siluriformes, Ariidae). Atlântica, Rio Grande, 5:1-5.

HUNTER, R. L. \& MARKERT, C. L. 1957. Histochemical demonstration of enzymes separated by zone electrophoresis in starch gels. Science, 125:1294-1295.

JOHNSON, A. G.; UTTER, F. M. \& HODGINS, H. O. 1973. Estimate of genetic polymorphism and heterozygosity in three species of rockfish (genus Sebastes). Comp. Biochem. Physiol, 44B:397-406.

JOHNSON, G. B. 1974. Enzyme polymorphism and metabolism. Science, 184:28-37.

1977. Assessing electrophoretic similarity: the problem of hidden heterogeneity. A. Rev. Ecol. Syst., 8:309-328.

KING, M. C. \& WILSON, A. C. 1975 . Evolution at two levels in human and chimpanzees. Science, 188:107-116.

LEWONTIN, R.C. 1984. Detecting population differences in quantitative characters as opposed to gene frequencies. Am. Naturalist, 123:115-124.

MARKERT, C. L. \& MOLLER, F. 1959. Multiple forms of enzymes: tissue, ontogenic and species specific patterns. Proc. natn. Acad. Sci. U.S.A., 45:753-763.

MICKEVICH, M. F. \& JOHNSON, M. S. 1976. Congruence between morphological and allozyme data in evolutionary inference and character evolution. Syst. Zool., 25:260-270.

MISHIMA, M. \& TANJI, S. 1981. Distribuição geográfica dos bagres marinhos (Osteichthyes, Ariidae) no complexo estuarino lagunar de Cananéia $\left(25^{\circ} \mathrm{S}, 48^{\circ} \mathrm{W}\right)$. Bolm Inst. Pesca, S Paulo, 8:157-172.

\& 1982. Nicho alimentar de bagres marinhos (Teleostei, Arïdae) no complexo estuarino lagunar de Cananéia $\left(25^{\circ} \mathrm{S}, 48^{\circ} \mathrm{W}\right)$. Bolm Inst. Pesca, S Paulo, 9:131-140.

NEI, M. 1971. Interspecific gene differences and evolutionary time estimated from electrophoretic data on protein identity. Am. Naturalist, 105:385-398.

1972. Genetic distance between populations. Am. Naturalist, 106:283-292.

1978. Estimation of average heterozygosity and genetic distance from a small number of individuals. Genetics, 89:583-590. 
NEVO, E. 1978. Genetic variation in natural populations: patterns and theories. Theor. Populati Biol., 13: 121-177.

PHAN, V. N.; SUZUKI, H.; GOMES, V. \& PASSOS, M. J. A. C. R. 1985. Notes on electropherograms of eye-lens, muscle proteins and zymograms of muscle esterases of fish collected during the First Brazilian Expedition to the Antarctica. Bolm Inst. oceanogr., S Paulo, 33(2):201-212.

RICHARDSON, B. J. 1982. Geographical distribution of electro-phoretically detected protein variation in Australian commercial fishes. I. Jack mackerel, Trachurus declivis Jenyns. Austr. J. mar. Freshw. Res., 33:917-926.

ROGERS, J. S. 1972. Measures of similarity and genetic distance. Studies in genetics. VII. Univ. Texas Publs, (7213): 145-153.

SAGE, R. D. \& SELANDER, R. K. 1975. Trophic radiation through polymorphism in cichlid fishes. Proc. natn. Acad. Sci. U.S.A., 72:4669-4673.

SAUNDERS, L. H. \& McKENZIE, J. A. 1971. Comparative electrophoresis of Arctic char. Comp. Biochem. Physiol., 38B:487-492.

SCHNEPPENHEIM, R. \& MacDONALD, C. M. 1984. Genetic variation and population structure of krill (Euphausia superba) in the Atlantic sector of Antarctic waters and off the Antarctic Peninsula. Polar Biol., 3:19-28.

SELANDER, R. K. 1970. Behaviour and génetic variations in natural populations. Am. Zool., 10:53-66.

\& JOHNSON, W. E. 1973. Genetic variation among vertebrate species. A. Rev. Ecol. Syst., 4:75-91.

SHAKLEE, J. B.; TAMARU, C. S. \& WAPLES, R. S. 1982. Speciation and evolution of marine fishes studied by the electrophoretic analysis of proteins. Pacif. Sci., 36:141-157.

SHAW, C. R. \& KOEN, A. L. 1968. Starch gel electrophoresis of enzymes. In: I. Smith, ed. Chromatographic and electrophoresis techniques. 2v, William Heinemann, Medical Books. p.325-364.

\& PRASAD, R. 1970. Starch gel electrophoresis of enzymes - a compilation of recipes. Biochem. Genetics, 4:297-320.

SIEGEL, S. 1981. Estatística nāo-paramétrica para as ciências do comportamento. São Paulo, McGraw-Hill do Brasil.
SMITH, P. J. 1979. Esterase gene frequencies and temperature relationships in the New Zealand snapper Chrysophrys auratus. Mar. Biol., 53:305-310.

\& FRANCIS, R. I. C. C. 1984. Glucosephosphate isomerase genotype frequencies, homozygous excess and size relationships in the sand flounder Rhombosolea plebeia. Mar. Biol., 79:93-98.

\& JAMIESON,

A. 1981. An excess of homozygotes at serum esterase locus in the Atlantic mackerel Scomber scombrus. Anim. Blood Grps biochem. Genet., 12:171-180.

\& FUJIO, Y. 1982. Genetic variation in marine teleosts: high variability in habitat specialists and low variability in habitat generalists. Mar. Biol., 69:7-20.

\& JAMIESON, A. 1980. Protein variation in the Atlantic mackerel Scomber scombrus. Anim. Blood Grps biochem. Genet., 11:23-30.

SMITHIES, O. 1955. Zone electrophoresis in starch gels: group variations in the serum protein of normal human adults. Biochem. J., 61:629-641.

SNEATH, P. H. \& SOKAL, R. R. 1973. Numerical taxonomy. San Francisco, W. H.Freeman. 573p.

SOMERO, G. N. \& SOULE, M. 1974. Genetic variation in marine fishes as a test of the niche-variation hypothesis. Nature, Lond., 249:670-672.

SUZUKI, H. \& PHAN, V. N. 1990. Electrophoretic study on intraspecific variations and interspecific relationships of marine catfishes (Siluriformes, Ariidae) of Cananéia (São Paulo, Brazil). 1. General proteins of eye-lens and skeletic muscle. Bolm Inst. oceanogr., S Paulo, 38(1):31-42.

THORPE, J. P. 1979. Enzyme variation and taxonomy: the estimation of sampling errors in measurements of interspecific genetic similarity. Biol. J. Linn. Soc., 11:369-386.

THORPE, J. P. 1982. The molecular clock hypothesis: biochemical evolution, genetic differentiation and systematics. A. Rev. Ecol. Syst., 13:139-168.

TSUYUKI, H.; ROBERTS, E. \& VANSTONE, W. E. 1965. Comparative zone electropherograms of muscle myogens and blood hemoglobins of marine and freshwater vertebrates and their application to biochemical systematics. J. Fish. Res. Bd Can., 22:203-213.

TURNER, B. J. \& GROSSE, D. J. 1980. Trophic differentiation in Ilyodon, a genus of stream-dwelling goodeid fishes: speciation versus ecological polymorphism. Evolution, 34: 259-270. 
YOSHIYAMA, R. M. \& SASSAMAN, C. 1983.

Morphological and allozymic variation in the stichaeid fish Anoplarchus purpurescens. Syst. Zool., 32:52-71.

(Received 17-Nov-88;

accepted 08-Aug-90) 